\title{
AGRIC FINANCING AND ITS IMPACT ON AGRICULTURAL GDP: AN ARDL
} APPROACH

\author{
(D) Ndubuaku Victor \\ $\mathrm{C.}^{1+}$ \\ iD Okoro Okoro E.U. ${ }^{2}$ \\ Bello Kabiru ${ }^{3}$ \\ Alozie Chiaka P.
}

\author{
${ }^{1,3,4}$ Department of Accountancy, Federal College of Agriculture Ishiagu, \\ Ebonyi State, Nigeria \\ ${ }^{2}$ Email: vondubuaku@gmail.com \\ ${ }^{2}$ Department of Banking and Finance, University of Nigeria Nsukka, Enugu \\ Campus, Enugu, Nigeria
}

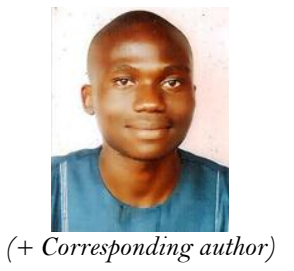

Article History

Received: 19 November 2018 Revised: 31 December 2018 Accepted: 6 February 2019

Published: 3 April 2019

\section{Keywords}

Agricultural production

Economic growth

public expenditure

Commercial banks

Agric credit guarantee scheme

Fund

ARDL

Loans and advances

GDP

Nigeria.

JEL Classification O47; O55; Q 14 .

\section{ABSTRACT}

This research investigated the impact of agricultural financing on agricultural sector contribution to GDP in Nigeria. The objective of the study was to determine whether agricultural financing had any significant impact on agricultural contribution to GDP in Nigeria. The dataset covered a 36year period from 1981-2016. Data was sourced from the CBN statistical Bulletin. The dependent variable was the Agricultural GDP (AGDP). The independent variables were government funding \{represented by Government Capital Expenditure on Agriculture (GCAG) and Government Recurrent Expenditure on Agriculture (GRAG) \}, Agric Credit Guarantee scheme Fund (ACGSF) and Commercial Banks' Credit, Loans and Advances to the Agricultural Sector (CBCA). Standard analytical tests were used to determine the properties of the data. The Auto Regressive Distributed Lagged regression model (ARDL) was used to estimate the data. The study found that government funding to agriculture and Agric Credit Guarantee scheme Fund (ACGSF) had a non-significant impact on Agricultural Contribution to GDP (AGDP). On the other hand, the study found that Commercial Banks' Credit, Loans and Advances to the Agricultural Sector (CBCA) had a positively significant impact on AGDP. The study recommended the sustenance of government policy that encouraged consistent injection of funds into agriculture. It advocated that a sizeable portion of Commercial Banks' credit should be channelled to agricultural production.

Contribution/Originality: This study contributes to the existing literature by investigating the impact of agricultural funding on agricultural GDP. This study uses new estimation methodology which is the ARDL approach. The paper contributes the first logical analysis by conducting a pre-test, estimation and diagnostic analyses. The paper's primary contribution is that government funding of the agricultural sector had no significant impact on agricultural GDP.

\section{INTRODUCTION}

Agriculture is considered as a basic building block for the Nigerian economy. Its role in economic growth and sustainable development, employment potentials, poverty reduction and export cannot be underestimated (Okoh, 2015).

The agricultural sector promotes structural transformation and diversification of the economy. It enables the economy full utilization of its factor endowment. It also ensures the country depends less on foreign agricultural products (Ishola et al., 2013). 
Previously, Nigeria was basically an agricultural economy and agriculture functioned as the bedrock of growth (Ogen, 2003). Shortly after Nigeria's independence, agriculture was a significant contributor to the Gross Domestic Product (GDP). It contributed about seventy percent of the GDP and employed a large portion of the working population. It also accounted for about ninety percent of foreign exchange earnings and government revenue. During this period, Nigeria became the second largest cocoa-producing nation and a net exporter and producer of palm produce, cotton, groundnut, hides and rubber (Alkali, 1997). This condition started changing adversely following the discovery of oil. Between 1970 and 1974, the proportion of agricultural exports to total exports deteriorated from forty three percent to about seven percent. This was largely due to the oil price hikes of $1973-$ 1974. This however resulted in huge income of foreign exchange and the consequent neglect of agriculture. From the 1970 s to the 1980s, agricultural exports had continued to decline by seventeen percent on an annual basis (Bakare and Fawehinmi, 2011). During the 1980s, the agricultural sector could no longer meet local food requirements, supply raw materials for industry and had lost it foreign exchange earning capacity. This was attributed to several socio-economic and environmental challenges. Domestic food supply had since become a major challenge in Nigeria and huge foreign exchange earnings were utilized in importing food. Consequently, Nigeria had been witnessing extreme hunger and poverty due to the lack of basic food items. The challenges of the agricultural economy could be traced to the increased dependence on oil and the consequent neglect of agriculture. After the discovery of oil, agricultural sector percentage contribution to GDP nosedived and had fluctuated between 10-22 percent from 1980 till 2015 (CBN, 2016). The effect of this is directly noticed on smallholder farmers. Smallholder farmers are majorly subsistence farmers and they produce majority of the food in Nigeria. They produce eighty five percent of total agricultural production and reside mainly in the rural areas (Okuneye, 1995; Rahji and Fakayode, 2009). Their productive capacity and growth are however hindered by inadequate and inaccessible credit facilities (Odoemenem and Obinne, 2010). Agricultural finance plays a very important role in agricultural productivity and development (Duong and Izumida, 2002). The provision of credit has been adjudged as a critical resource in the advancement of the agricultural sector. However, access to agricultural finance has been seriously incapacitated in Nigeria (Swinnen and Gow, 1999).

It has been opined that credit availability would lead to an increase in agricultural production, reduced unemployment rate and higher incomes. It was estimated that only five percent of the farmers in Nigeria and about fifteen percent in Asia and Latin America had access to formal credit (Bali, 2001). In a bid to correct this position, the Agricultural credit Guarantee Scheme Fund (ACGSF) was established in 1977. The fund was designed to encourage banks to increase its loans and advance to the agricultural sector. The fund was therefore to provide guarantees against adverse risk associated with agricultural lending. From 1981-2015, the ACGSF had however only guaranteed loans estimated at N75.5billion. Commercial Banks' direct credit to the agricultural sector from 1981-2016 was valued at N3.48 trillion. Also from 1981-2016, Government capital expenditure on agriculture was valued at N1.19trillion and Government recurrent expenditure on agriculture was valued at N525.11 billion respectively (CBN, 2016). As such, it was imperative to determine whether agricultural funding had stimulated the agricultural sector's performance in Nigeria. This study therefore sought to determine the nexus between agricultural financing and its performance in relation to the GDP in Nigeria.

\section{LITERATURE REVIEW}

\subsection{Conceptual Reviere}

Agricultural finance refers to funds employed and invested on the agricultural sector with the aim of promoting social welfare. It refers to the sourcing of funds and making it available for agricultural production and purposes. It simply means the acquisition and utilization of funds for agricultural purposes. It includes both private and public funds and could exist in the form of loans, investment, grants etc. Sources of agricultural finance may include the money and capital markets, government and non-governmental organizations. Public funds are subsidized funds 
while private funds are unsubsidized notwithstanding their price (Schreiner and Yaron, 2001; Obansa and Maduekwe, 2013). Agricultural financing can be divided into the non-debt (non -leverage) and debt (leverage) categories. Debt represents funds that have strict contractual monetary obligations on a country's resources while non-debt funds don't require fixed or compulsory servicing obligations on the nation. To survive in the long-run, a country's debt- servicing ability must increase at a rate greater than the rate of its debt burden (Ariyo, 1999).

As suggested by development theorist, agricultural sector advancement is crucial for the structural transformation of the economy. It is opined that the agricultural sector transfers to the industrial sector the excess of investible resources generated in agriculture (Kuznets, 1961). Consequently, for a sustained economic growth and industrial advancement, the agricultural sector (implicitly or explicitly) must extract and develop its resources (Obansa and Maduekwe, 2013). Agricultural financing therefore promotes investment and adoption of technology necessary to spur desired economic growth. The appropriate reflection of the agricultural development would therefore be the agricultural contribution in the national product.

\subsection{Theoretical Review}

\subsubsection{Wagner's Law of Increasing Public Expenditure}

This theory was first propagated by German economist "Wagner". He based his law of increasing state activities on historical facts relating to Germany. He believed that there was a natural tendency for the activities of various sections and sectors of the government to rise both intensively and extensively. He therefore pointed that, there was a functional relationship between a country's economy growth and government activities. He concluded that the government sector usually grew faster than the economy. Wagner (1893) as quoted by Ibok and Bassey (2014) opined that government spending increased in a higher proportion compared with income. It suggested that the income elasticity of demand for public services was positive and greater than unity. This theory posits a positive relationship between government spending and income and a unidirectional causality from government spending to income. However, Musgrave believed that Wagner was thinking of proportion of public sector in the economy. Landau (1983) also believed that this theory could be applied to other countries and not limited to Germany. Wagner's Law had been tested in several functional forms since the 1960s. Six variants of the law were examined. The variables used were Agricultural capital expenditure (ACEX) (proxy for public expenditure); Agricultural contribution to Gross Domestic Product (AGDP) (proxy for economic growth); Agricultural Population (APOP) (proxy for population) and Agricultural Budget Deficit (ABDF) as shown in Table 1.

Table-1. Six Versions of Wagner's Law of Increasing Public Expenditure.

\begin{tabular}{l|l|l}
\hline Equation & Functional Forms & Version \\
\hline 1 & $\log (A C E X t)=a 1+b 1 \log (A G D P t)+u 1 t$ & Peacock and Wiseman $(1961)$ \\
\hline 2 & $\log (A C E X t / A P O P t)=a 2+b 2 \log (A G D P t / A P O P t)+u 2 t$ & Gupta $(1967)$ \\
\hline 3 & $\log (A C E X t)=a 3+b 3 \log (A G D P t / A P O P t)+u 3 t$ & Goffman $(1968)$ \\
\hline 4 & $\log (A C E X t / A G D P t)=a 4+b 4 \log (A G D P t / A P O P t)+u 4 t$ & Musgrave $(1969)$ \\
\hline 5 & $\log (A C E X t)=a 5+b 5 \log (A G D P t)+u 5 t$ & P-W Modified version by Mann \\
& $\begin{array}{l}\log (A C E X t / A G D P t)=a 6+b 6 \log (A G D P t / A P O P t)+ \\
b 7(A B D F t / A G D P t)+u 6 t\end{array}$ & Murthy (1994) \\
\hline 6 & \multicolumn{2}{l}{ Source: Ibok and Bassey (2014). }
\end{tabular}

Peacock and Wiseman (1961) adopted Equation 1. They posited that increased agricultural expenditure (ACEX) was as a result of increase in Agricultural Gross Domestic Product (AGDP). Gupta (1967) modified Wagner's law by including population increase (APOP) in the model. He suggested that growth in per capita agricultural expenditure (ACEX/APOP) was dependent on the growth in agricultural Gross Domestic Product per capita (AGDP/APOP) as depicted in Equation 2. Goffman (1968) however adopted another mathematical form known as the "absolute version of the law". He posited that during the development process, the GDP per capita 
increase should be lower than the rate of public sector activities increase. He agreed that agricultural expenditure (ACEX) is dependent upon the growth in agricultural Gross Domestic Product per capita (AGDP/APOP) as depicted in Equation 3. Furthermore, Musgrave (1969) suggested that during the development process, the public sector share to GDP increases as the GDP per capita increased, as shown in Equation 4. Musgrave suggested that growth in ACEX in AGDP depends upon AGDP per capita. Mann (1980) however modified Peacock and Wiseman (1961) as shown in Equation 5. Mann posits that agricultural expenditure (ACEX) share to GDP (AGDP) is a function of GDP (AGDP). Finally, Equation 6 was modified and renamed "Augmented Version" by Murthy (1994). He opined that as economic development progresses, the budget deficit ratio would also increase especially in the case of developing countries. This occurred because government revenue increases in less proportion to expenditure. This problem would be further reduced if developing countries adopted financial and economic liberation policies (Murthy, 1994). Halicioglu however suggested that, for a more inclusive law, we included more explanatory variables relating to economic development and public spending such as degree of urbanization, budget deficits, among others (Halicioĝlu, 2003).

\subsubsection{Commercial Loan Theory}

This theory is additionally called the "Real Bills Doctrine". It stipulates that commercial banks should only lend to profitable business organizations on a short term period and ensure the loans can self-liquidate. A loan is self-liquidating if the loan finances a transaction and the transaction in return generates the funds to repay the loan (Jhingan, 2004). The Real Bills Doctrine can easily be illustrated as a transaction between a bank and a business that results in the creation of money in the economy. For example, a seed company supplies One Hundred Thousand Naira $(\$ 100,000)$ worth of maize seeds to a farmer. An invoice is written with payment due in 90 days. The farmer agrees to repay the credit after planting, harvesting, processing and sales over the 90days period. In effect, the supplier has created commercial paper (a "real bill" that is not secured, but represents tangible goods in process) that has a value of One Hundred Thousand Naira (100,000). Rather than wait to be paid, the supplier can sell the paper to a bank at its present discounted value of say Ninety Eight Thousand Naira ( $\$ 98,000)$. The paper is monetized by the bank and the bill is collected at full value.

The theory also posits that the composition of commercial bank's assets should consist primarily of loans advanced to business organizations for their working capital (Mbat, 2001). This theory postulates that if commercial banks limit their advances to productive, self-liquidating, short term liquidating loans; the central bank should also limit their advances to banks on the security of those short term loans. This principle would ensure liquidity of the commercial banks and adequate supply of money for the economy.

The Central Bank increases or reduces bank reserves by rediscounting approved loans when business expands or declines and the volume of trade increases or reduces respectively. Commercial banks provide funds to the agricultural sector by granting of loans to farmers to finance their working capital needs.

The liquidation of the loans is expected to come from the production, distribution and sale of their farm produce. Some economists have however criticized the doctrine. The economists that advocated the quantity-theory suggested that central banks should focus on stabilizing the quantity of money, preferring active open-market policies like the acquisition of public debt to drive liquidity in markets and stabilize currency. The doctrine was most strongly criticized by economists supporting free banking. They argued that the government shouldn't be involved in money supply management. They opined that open commercial competition provides the optimal stabilization of money creation.

\subsection{Empirical Review}

Enrique et al. (2012) examined the effect public spending (expenditure) had on agricultural growth in Indonesia. They employed a study time frame from 1976-2006. The variables for the study included public expenditure on 
irrigation and agriculture; fertilizer subsidies and agriculture gross domestic product per capita growth. The study used both ordinary least squares and generalized method of moments econometric techniques for analysis of the data. The study concluded that public expenditure on irrigation and agriculture had a positive but not significant impact on agricultural growth in Indonesia.

Talknice and Mufaro (2014) studied the impact of agricultural expenditure on economic performance in Zimbabwe. The time series data span from 1980-2005. They Ordinary Least Square (OLS) model technique was used for data analysis. They employed the following variables; Gross Domestic Product (GDP), agriculture exports (EXPO), money supply (MSS), agricultural expenditure (AGRICEXP), total government expenditure (less agriculture expenditure)(GVTEXP), subsidies to the agriculture sector from the central bank (SUBS), dummy for drought (DD). They found that a positively significant relationship existed between agriculture expenditure and economic growth in Zimbabwe for the study period.

Abbas et al. (2016) examined Pakistan's government expenditure and the degree of impact it had on the agricultural sector and economic growth. The time frame covered the period 1983-2011. The variables employed for the study included Government expenditure on agriculture, agricultural outputs and GDP. They employed the Augmented Dickey-Fuller (ADF), Johansen Co-integration test and Ordinary Least Square (OLS) technique as analytical tools. The Johansen Co-integration test results showed the existence of a long-run relationship between government expenditure on agriculture, agricultural outputs and economic growth in Pakistan. On the other hand, the regression analysis revealed that agricultural outputs and government expenditure had a positively significant impact on GDP in Pakistan.

Comfort and Arigbede (2016) examined agricultural productivity and the effect on economic growth in Nigeria. They sought to determine whether agricultural productivity had a significant effect on economic growth in Nigeria. They used annualised time series data from 2000 to 2014. The study employed the Ordinary Least Square (OLS) method for analysis. The study suggested that there was a long-run relationship between agricultural productivity and economic growth. The variables for the study were the agricultural sector contribution to GDP, gross expenditure on agriculture and gross access to bank (agricultural) loans and credit. The study concluded that farmer's access to credit and loans did not significantly impact economic growth in Nigeria among others.

Kareem et al. (2013) studied the factors that influenced agricultural output and productivity in Nigeria. The study scope was from 1977-2011. The study analysed the variables using regression technique, descriptive analysis and the granger causality tests. The variables for the study were food import value (FOOD), interest rate (IRATE), commercial banks' loans on Agriculture (LOAN), GDP growth rate (GDP) and foreign direct investment (FDI). The result showed that ninety five percent of the variations in the agricultural output were explained by the explanatory variables. They concluded that foreign direct investment; commercial bank loan, interest rate and food import value had positive and significant impact on agricultural output among others.

Udoka et al. (2016) studied the commercial banks' credit advances to the agricultural sector and its effect of on agricultural output in Nigeria. The study covered the period 1970-2014. The study employed the ordinary least squares regression technique to estimate the variables. The study concluded that there was a positive and significant relationship between Agric Credit Guarantee Scheme Fund, commercial banks credit to the agricultural sector, government expenditure on agriculture and agricultural production in Nigeria respectively. It however opined that there was no significant relationship between interest rate and agricultural output.

Dang (2017) studied the impact of the credit guarantee system on Hungarian economy. The study sought to determine the significance of the credit guarantee system on the banking system, SMEs and the Hungarian economy. The time frame for the study was 2000-2012. This study focused on assessing the impact of the credit guarantee system for the Hungarian economy in the following areas: economic development, credit operations, SMEs, labour. Dependent variables employed included GDP (Gross Domestic product), LSME: loan availability to SMEs by banks, VDS: value added of SMEs in Hungary, ESMTT: Employee of SMEs/Total employees, Net sale 
Guaranteed loans, Interest paid Guaranteed loans, Fixed tangible asset ratio Guaranteed loans, TL: Total loans by banks in Hungary. The independent variables included GRT: guaranteed loans by credit guarantee system, GRLE: guaranteed loans by credit guarantee system/ Total loans to SMEs by banks. The VAR model Granger causality, Linear-log model were employed in analysis. The study concluded that the credit guarantee system contributed to the development of the Hungarian economy among others.

Onwumere et al. (2012) empirically analysed the Agric Credit Guarantee Scheme Fund (ACGSF) and its impact of on three agricultural subsectors (crop production, livestock and fisheries) and on the whole agricultural sector in Nigeria. The study took time series data spanning 1978 to 2008. The study employed the two-variable regression model for analysis. It found that the ACGS Fund had a positively significant impact on these three agricultural subsectors (i.e. crop production, livestock and fisheries) and aggregate agricultural productivity respectively.

Edet et al. (2016) examined the impact of institutional funding on agricultural labour productivity in Nigeria. The study employed the co-integration and error correction model to analyse the variables. The study employed time series data which spanned 1978-2012. The result showed that there was a significant impact of government capital expenditure on agricultural sector (GCEAt), real amount of loan guaranteed by Agric Credit Guarantee scheme Fund (ACGSF) (GFSt), past value of loan guaranteed by Agric Credit Guarantee Scheme Fund (ACGSF) (GFSt-1) and policy shift (PSt) on agricultural labour productivity respectively. However, Commercial Bank's Credit to Agricultural Sector (CBCAt) had not significantly impacted on agricultural labour productivity in Nigeria during the period. Oparinde et al. (2017) examined the influence of Agric Credit Guarantee Scheme Fund on fishery development in Nigeria. They obtained time-series data from 1981 to 2012. The variables were analysed using descriptive statistics, growth function and autoregressive distributed lagged model. The study showed that fishery sub-sector was the least financed in the agricultural sector of the economy. It concluded that; in the long run, volume of loan to agriculture from the Agric Credit Guarantee Scheme Fund had a positive relationship with fishery contribution to agricultural GDP.

Orok and Ayim (2017) investigated the ACGS Fund and its impact on agricultural development in Nigeria. The time frame for the study was 1981-2016. The specific objectives were to determine whether ACGSF had a significant relationship with the output of the crop sector, livestock sector, and the fishery sector in Nigeria. The work employed multiple OLS regression technique to analyse the variables. They found ACGSF had a positively significant relationship with agricultural sector development in Nigeria. They also discovered that ACGSF had disbursed more funds and impacted greater on the crop sector over the livestock and fishery sector.

Zakaree (2014) examined the ACGS Fund and its effect of on domestic food supply in Nigeria. The following proxies were employed for the independent variables; ACGS Fund, annual average rainfall (AAR) and rural population (RP). Domestic food supply (DFS) was the dependent variable. They used Ordinary Least Square (OLS) to analyse data and unit root test as the diagnostic tool. The result showed that the rural population (RP) had a positively significant impact on domestic food supply (DFS) while Agric Credit Guarantee Scheme Funds (ACGSF) and annual average rainfall (AAR) had negatively significant impact on domestic food supply (DFS) in Nigeria.

Matthew and Mordecai (2016) studied public agricultural expenditure and its effect on agricultural output in Nigeria. The study period spanned from 1981 to 2014. Analytical tools employed included the granger causality diagnostic test, augmented dickey-fuller test, error correction method (ECM) and Johansen cointegration test. The study concluded that public agricultural expenditure had a negative and significant impact on agricultural output. It further posited that commercial banks loans to the agricultural sector and interest rate had a positive and nonsignificant impact on agric output in Nigeria.

Andrew (2015) analysed agricultural financing and its effect on output for sustainable economic development in Nigeria. Agricultural Credit Guarantee Scheme (ACGS) was the proxy for agricultural financing while GDP was the proxy for output. The study was analysed using multiple regression technique. The study found a nonsignificant relationship between ACGS and GDP. 
Idoko et al. (2012) studied the effect of government expenditure on the Nigerian agricultural output using data from 1975 to 2010 . The variables for this study included foreign direct investment on agricultural sector, annual rainfall, government expenditure on agricultural sector, Agric Credit Guarantee scheme Fund, and commercial bank loans and advances to the agricultural sector. The OLS model was used to estimate the result. The relationship that existed between government expenditure on agriculture and Nigerian agricultural sector output was found to be significant and positive during the evaluation period.

Friday et al. (2016) examined the impact of the credit supply, and various commercial bank loan schemes on agricultural sector production in Nigeria. They employed vector autoregressive (VAR) approach for data analysis. Time series data was sourced from Central Bank of Nigeria Statistical Bulletin over the sample period of 1981-2013. The study concluded that ACGSF had no significant impact on agricultural sector performance while commercial banks loans to agricultural sector had a significant impact on agricultural production.

\subsection{Gap of the Study}

Several studies have been conducted on this subject matter with dissenting views. For example, Matthew and Mordecai (2016) posited that government agricultural expenditure had a negative and significant impact on agricultural output while Idoko et al. (2012) opined that government expenditure on agriculture had a positive and significant impact on agricultural sector output. The scope of most studies was limited to the year 2014. This study however extended to the year 2016. Also, majority of the earlier studies conducted employed the Ordinary Least Square techniques. This study however employed a relatively new estimation technique; the Auto Regressive Distributed lagged Technique (ARDL). This technique included the impact of lagged variables on the dependent variable.

\section{METHODOLOGY}

Most empirical studies found that agricultural performance was essential to economic growth in Nigeria. The theoretical foundation of this study was based on Wagner's Law of increasing public expenditure. The law stipulates that increased agricultural expenditure (ACEX) was as a result of increase in Agricultural Gross Domestic Product (AGDP). This study adopted the law in reverse. The study therefore adapted and modified a related study by Evbuomwan et al. (2018). The study employed descriptive and ex-post facto research design for the study. The data was of secondary nature represented by annualized time series drawn from the CBN statistical bulletin. The study covered the period 1981-2016.

\subsection{Model Specification}

This study estimated the following model:

$A G D P=f(C B C A, A C G S F, \mathrm{GCAG}, \mathrm{GRAG})$

$L A G D P_{t}=\alpha+\beta_{t} L C B C A_{t}+\beta_{2} L G C A G_{t}+\beta_{s} L G R A G_{t}+\beta_{t} L A C G S F_{t}$

Where

$\alpha=$ Intercept; $\beta_{n}, \beta_{3}, \beta_{s}, \beta_{t}=$ Coefficient of the explanatory variable (slope); $\varepsilon=$ Represents the error term in the model; AGDP $=$ Agricultural Contribution to GDP; $\mathrm{CBCA}=$ Commercial Banks Credit to Agriculture; ACGSF $=$ Agric Credit Guarantee scheme Fund; GCAG = Government Capital Expenditure on Agriculture; GRAG= Government Recurrent Expenditure on Agriculture. The " $L$ " connotes the log-transformed variables. Logarithms help to resolve the problem of heteroscedasticity. 


\subsection{A Priori Assumptions}

The a priori assumptions of this model suggested that agricultural funding on agricultural GDP had a positive sign and coefficients, which implied a positive relationship between the variables. Thus the following is the a priori

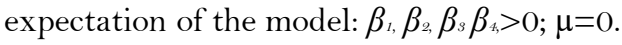

\section{DATA ANALYSIS AND DISCUSSION OF FINDINGS}

An array of diagnostic tests was carried out on the multiple linear regression model in line with the requirements of the Classical Linear Regression Model (CLRM). These tests included Augmented Dickey-Fuller Test, White's Hetereoskedasticity Test, Ramsey Regression Error Specification Test (RESET), the CUSUMQ, Breusch Godfrey Serial Correlation Tests, Durbin Watson Test and CUSUM Test. The data were analyzed using the ARDL technique. The significance level was $0.05 \%$.

\subsection{Descriptive Analysis}

Table-2. Showing Descriptive Analysis.

\begin{tabular}{|c|c|c|c|c|c|}
\hline Variables & AGDP & ACGSF & CBCA & GCAG & GRAG \\
\hline Mean & 5205.168 & 2887.161 & 96.63611 & 33.12500 & 14.58639 \\
\hline Median & 1384.005 & 244.0600 & 32.15000 & 6.575000 & 4.615000 \\
\hline Maximum & 21523.51 & 12997.00 & 525.9000 & 112.4400 & 65.40000 \\
\hline Minimum & 17.05000 & 24.65400 & 0.600000 & 0.250000 & 0.010000 \\
\hline Std. Dev. & 6716.305 & 4077.658 & 146.3819 & 39.82360 & 18.68870 \\
\hline Skewness & 1.104395 & 1.146496 & 1.806164 & 0.782137 & 1.155554 \\
\hline Kurtosis & 2.823692 & 2.791400 & 5.033511 & 2.064852 & 3.251311 \\
\hline Jarque-Bera & 7.364753 & 7.951984 & 25.77613 & 4.982181 & 8.106571 \\
\hline Probability & 0.025163 & 0.018761 & 0.000003 & 0.082820 & 0.017365 \\
\hline Sum & 187386.0 & 103937.8 & 3478.900 & 1192.500 & 525.1100 \\
\hline Sum Sq. Dev. & $1.58 \mathrm{E}+09$ & $5.82 \mathrm{E}+08$ & 749968.6 & 55507.18 & 12224.36 \\
\hline Observations & 36 & 36 & 36 & 36 & 36 \\
\hline
\end{tabular}

Source: Authors compilation
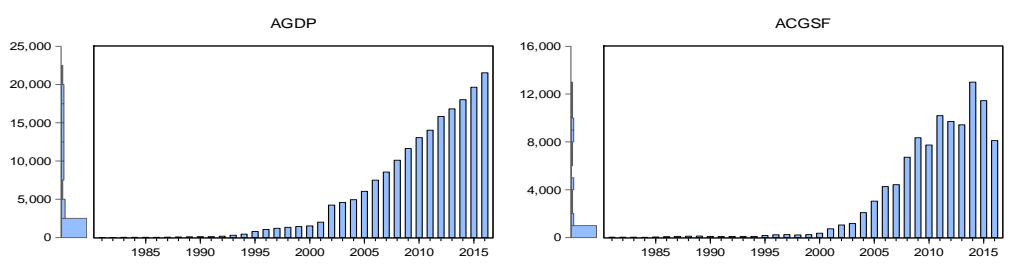

CBCA

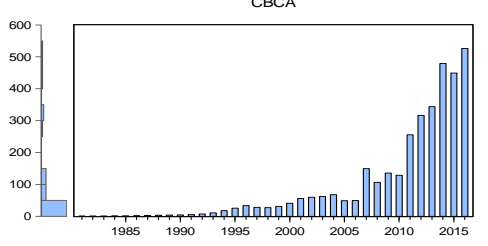

GCAG
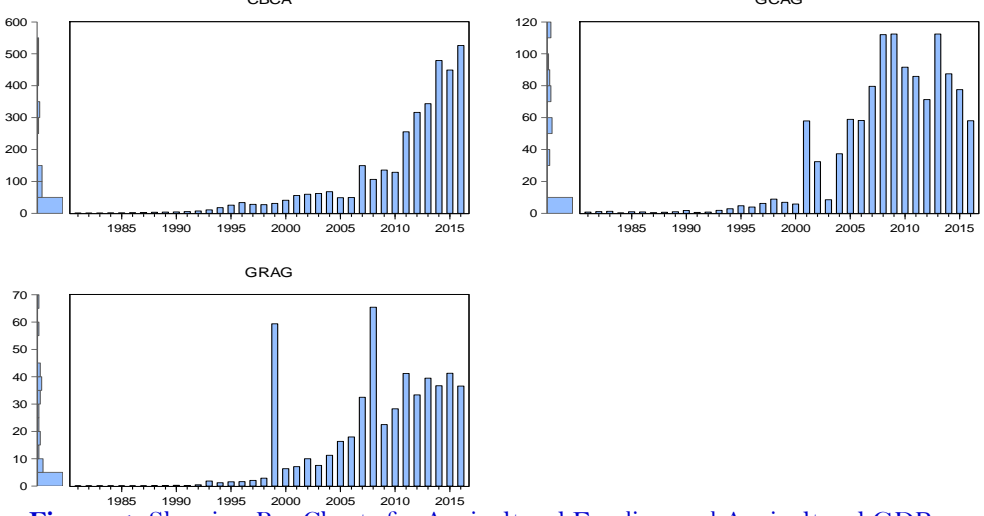

Figure-1. Showing Bar Charts for Agricultural Funding and Agricultural GDP.

\subsubsection{Agricultural Contribution to GDP (AGDP)}

With reference to Table 2 and Figure 1 above, AGDP showed a continuous increase during the study period. The lowest value was N17.05 (Billion) in 1981 and the highest value was N21, 523 (Billion) in 2016. The mean 
value was N5, 205 (Billion). The data was positively skewed to the right $(\mathrm{S}>0)$ and mesokurtic ( $\mathrm{k}=3)$. Jarque-Bera $(\mathrm{JB})$ statistics $(\mathrm{P}<0.05)$ suggested that the data set was not normally distributed.

\subsubsection{Agric Credit Guarantee Scheme Fund (ACGSF)}

With reference to Table 2 and Figure 1 above, ACGSF showed a gradual rise and fluctuating pattern during the study period. The lowest value was N 24.65 (Billion) in 1984 and the highest value was N12, 997 (Billion) in 2014. The mean value was N 2887.16 (Billion). The data was positively skewed to the right (S>0) and mesokurtic $(\mathrm{k}=3)$. Jarque-Bera $(\mathrm{JB})$ statistics $(\mathrm{P}<0.05)$ suggested that the data set was not normally distributed.

\subsubsection{Commercial Bank' Credit, Loans and Advances to the Agricultural Sector (CBCA)}

With reference to Table 2 and Figure 1 above, CBCA showed a gradual rise pattern during the study period. The lowest value was N 0.6 (Billion) in 1981 and the highest value was N 525.90 (Billion) in 2016. The mean value was N96.64 (Billion). The data was positively skewed to the right $(\mathrm{S}>0)$ and leptokurtic $(\mathrm{k}>3)$. Jarque-Bera (JB) statistics $(\mathrm{P}<0.05)$ suggested that the data set was not normally distributed.

\subsubsection{Government Capital Expenditure on Agriculture (GCAG)}

With reference to Table 2 and Figure 1 above, GCAG showed a gradual rise and fluctuating pattern during the study period. The lowest value was N 0.25 (Billion) in 1984 and the highest value was N 112.44 (Billion) in 2009. The mean value was N 33.13 (Billion). The data was positively skewed to the right $(\mathrm{S}>0)$ and platykurtic $(\mathrm{k}<3)$. Jarque-Bera $(\mathrm{JB})$ statistics $(\mathrm{P}>0.05)$ suggested that the data set was normally distributed.

\subsubsection{Government Recurrent Expenditure on Agriculture (GRAG)}

With reference to Table 2 and Figure 1 above, GRAG showed a gradual rise pattern during the study period with outliers in the years 1999 and 2008. The lowest value was N 0.01 (Billion) in the years 1981-1983, and the highest value was N 65.4 (Billion) in 2008. The mean value was N 14.59 (Billion). The data was positively skewed to the right $(\mathrm{S}>0)$ and mesokurtic $(\mathrm{k}=3)$. Jarque-Bera $(\mathrm{JB})$ statistics $(\mathrm{P}<0.05)$ suggested that the data set was not normally distributed.

\subsection{Preliminary Test}

The dataset were $\log$ transformed to improve linearity, stationarity and heteroskedacity. The Augmented Dickey-Fuller unit root test was carried out to determine the stationarity properties of the dataset and to specify the appropriate estimation technique to be employed.

\subsubsection{Augmented Dickey-Fuller Unit Root Test}

Table-3. Showing Augmented Dickey-Fuller (AD-F) Unit Root Test.

\begin{tabular}{|c|c|c|c|c|c|c|}
\hline Variable & ADF Stat & $1 \%$ & $5 \%$ & $10 \%$ & Pvalue & Inference \\
\hline LACGSF & -3.36 & $-2.63 * * *$ & $-1.95 * *$ & $-1.61^{*}$ & $0.00<0.01$ & $\mathrm{I}(1)$ \\
\hline LAGDP & -3.80 & $-3.63^{* * * *}$ & $-2.95^{* *}$ & $-2.61^{*}$ & $0.00<0.01$ & $\mathrm{I}(1)$ \\
\hline $\mathrm{LCBCA}$ & -4.60 & $-2.63 * * *$ & $-1.95^{* *}$ & $-1.61^{*}$ & $0.00<0.01$ & $\mathrm{I}(1)$ \\
\hline LGCAG & -7.26 & $-2.63 * * *$ & $-1.95^{* *}$ & $-1.61^{*}$ & $0.00<0.01$ & $\mathrm{I}(1)$ \\
\hline LGRAG & -7.32 & $-2.63 * * *$ & $-1.95^{*} *$ & $-1.61^{*}$ & $0.00<0.01$ & $\mathrm{I}(1)$ \\
\hline
\end{tabular}

The AD-F test showed that all the variables were stationary at first order as seen in Table 3. Consequently, the suitable estimation technique used was the Auto Regressive Distributed Lagged (ARDL) technique. 


\begin{tabular}{|c|c|c|c|c|c|c|c|c|c|}
\hline LAGDP $_{\mathrm{t}}=$ & 1.35 & $+0.74 \mathrm{LAGDP} \mathrm{P}_{\mathrm{t}-1}$ & $+0.16 \mathrm{LCBCA}_{\mathrm{t}}$ & $+0.05 \mathrm{LGCAG}_{\mathrm{t}}$ & +0.07 LGRAG $_{t}$ & \multicolumn{2}{|c|}{$+0.0001 \mathrm{LACGSF}_{\mathrm{t}}$} & $+0.2 \mathrm{LACGSF}_{\mathrm{t}-1}$ & $-0.3 \mathrm{LACGSF}_{\mathrm{t}-2}$ \\
\hline $\mathrm{SE}$ & $(0.38)$ & $(0.07)$ & $(0.07)$ & $(0.04)$ & $(0.05)$ & \multicolumn{2}{|c|}{$(0.07)$} & $(0.1)$ & $(0.12)$ \\
\hline t-stat & $\{3.52\}$ & $\{9.52\}$ & $\{2.42\}$ & $\{1.06\}$ & $(1.51)$ & \multicolumn{2}{|l|}{0.002} & $\{1.62\}$ & $\{-2.9\}$ \\
\hline Pvalue & {$[\mathrm{p}<0.05]$} & {$[\mathrm{p}<0.05]$} & {$[\mathrm{p}<0.05]$} & {$[\mathrm{p}>0.05]$} & {$[\mathrm{p}>0.05]$} & \multicolumn{2}{|l|}{$[\mathrm{p}>0.05]$} & {$[\mathrm{p}>0.05]$} & {$[\mathrm{p}<0.05]$} \\
\hline Expectation & \multirow{2}{*}{\multicolumn{2}{|c|}{ Adjusted $\mathrm{R}^{2}$}} & + & + & + & \multicolumn{2}{|l|}{+} & + & + \\
\hline $\mathbf{R}^{2}$ & & & \begin{tabular}{l|l|} 
F-stat \\
\end{tabular} & DW & \multicolumn{2}{|l|}{ BG-F } & \multicolumn{2}{|c|}{$x^{2}($ HET $)$} & RESET-F \\
\hline $99.7 \%$ & & $9.65 \%$ & 1370.18 & 1.73 & 0.71 & & 0.26 & & 0.29 \\
\hline
\end{tabular}




\subsection{Data Analysis}

The analysis in Table 4 indicated a positively significant impact between one-year lagged values of AGDP and the current values of AGDP. It posited a positively significant impact between current values CBCA and the current values of AGDP. It indicated a non-significant impact between current values of GCAG and Current values of AGDP. It indicated a non-significant impact between current values of GRAG and current values of AGDP. It however, indicated a non-significant impact between current values of ACGSF and Current values of AGDP. It also indicated a non-significant impact between one-year lagged values of ACGSF and the current values of AGDP. Finally, two lagged values of ACGSF indicated a negatively significant impact on current values of AGDP. The goodness of fit $\left(\mathrm{R}^{2}=99\right.$ percent) and the (Adjusted $\left.\mathrm{R}^{2}=99.8 \%\right)$ of the equation showed a very strongly-related association between the dependent and independent variables. The $\mathrm{F}$-stat $(1370.18 ; \mathrm{P}<0.05)$ suggested that the equation was significant with a five percent error limit. Therefore, we can statistically rely on its inference. The Durbin-Watson analysis indicated no suspicion of first order autocorrelation which was confirmed by the BG-F Serial Correlation LM Test statistic. The $x^{2}$ (HET) confirmed the model to be homoscedastic. The RESET-F suggested that the model was correctly specified. The CUSUM and the CUSUM of Squares test suggested that the model was stable as it fitted between the lower and the upper bounds see Figure 2 and Figure 3. Evidently, the model was BLUE (Best Linear Unbiased Estimator).

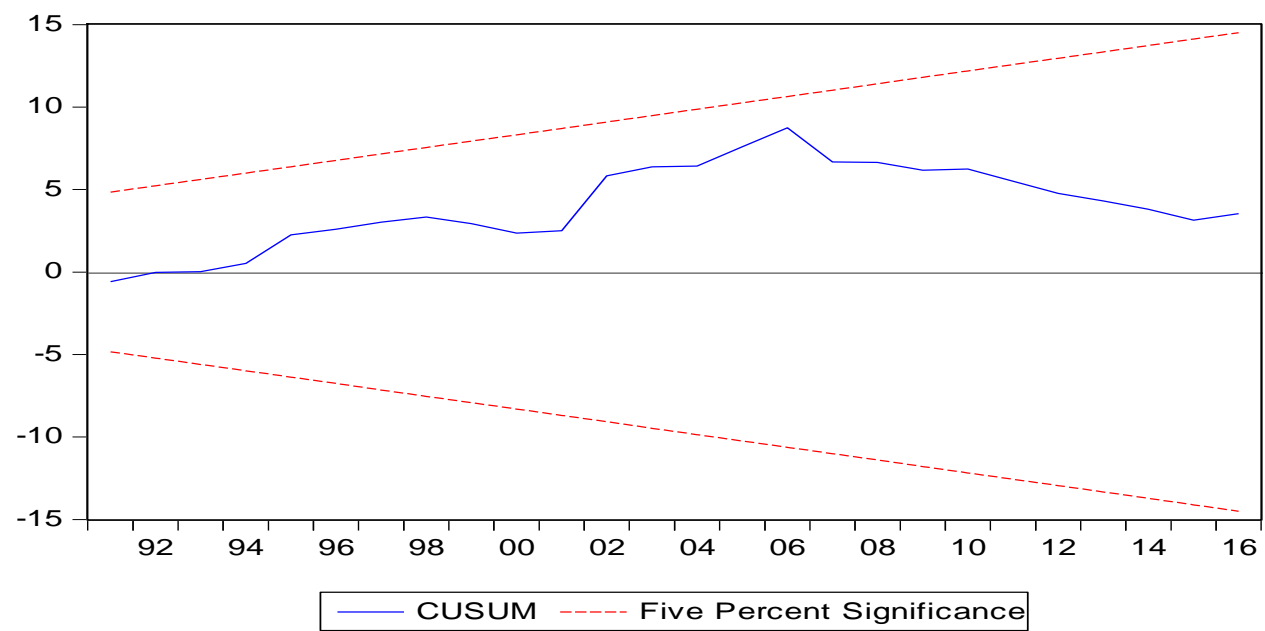

Figure-2. Showing CUSUM test for Agricultural Financing and Agricultural GDP.

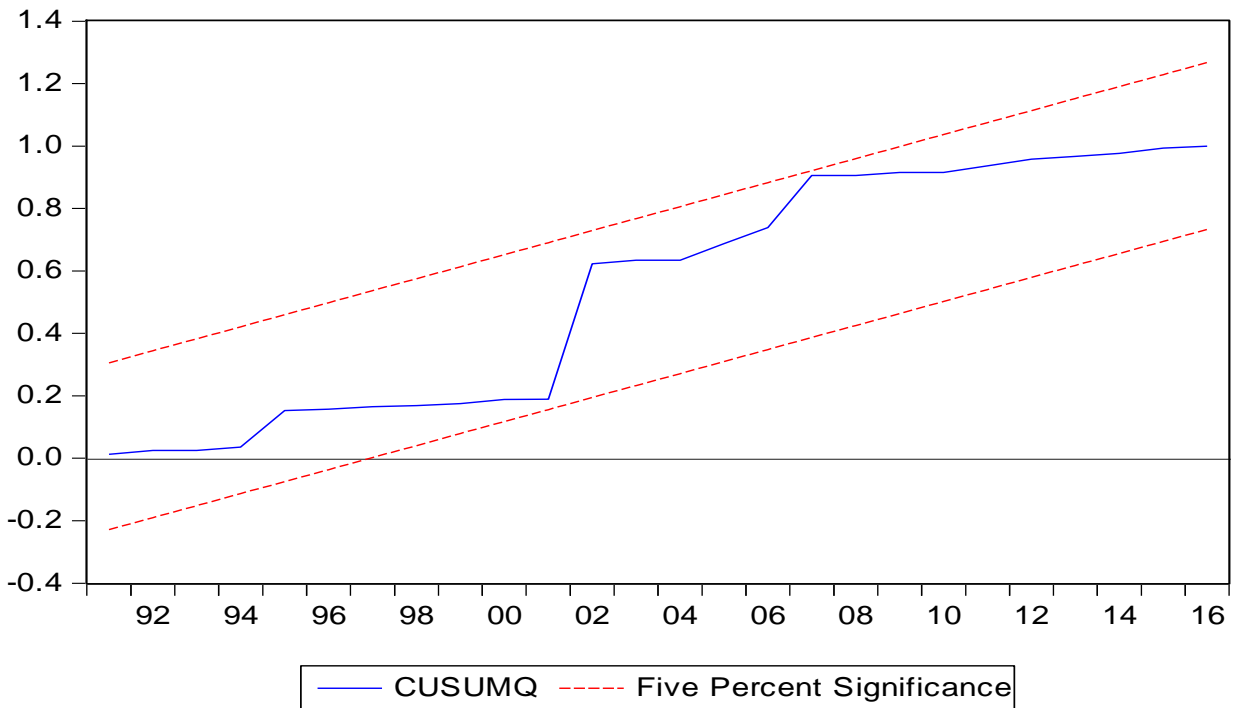

Figure-3. Showing CUSUMQ test for Agricultural Financing and Agricultural GDP. 


\section{SUMMARY, CONCLUSION AND RECOMMENDATION}

This study analysed the impact of agricultural financing on agricultural sector contribution to economic growth in Nigeria. The dataset covered a 36year period from 1981-2016. The Auto Regressive Distributed Lagged (ARDL) Regression technique represented the main estimation method combined with other general/standard and diagnostic tests.

The study made the following conclusions;

A. There was a positive and significant impact between the current values of CBCA and AGDP. It suggested an increase in the Commercial Banks Direct Credit to the agricultural sector would lead to a positive and significant increase in the value of Agricultural Sector's Contribution to GDP. This agreed with Egwu (2016); Friday et al. (2016) and Ibe (2014). This conformed to the a priori expectation.

B. A non-significant impact between GCAG, GCAG, GRAG, ACGSF, one-year lagged value of ACGSF and AGDP respectively. This conformed to the study of Ibe (2014); Andrew (2015) and Friday et al. (2016) that government funding of agriculture did not have any significant impact of agricultural productivity in Nigeria. It however, disagreed with Egwu (2016) which found a significant relationship between ACGSF and Agricultural Sector Output percentage to GDP (ASOGDP).

The study recommended the sustenance of government policy that encouraged consistent injection of funds into agriculture. It advocated that a sizeable portion of Commercial Banks' credit should be channelled to agricultural production. Furthermore, the interest rates should be reduced to make them affordable to the real farmers.

Funding: This study received no specific financial support.

Competing Interests: The authors declare that they have no competing interests.

Contributors/Acknowledgement: All authors contributed equally to the conception and design of the study.

\section{REFERENCES}

Abbas, A.C., Y. Jiang, A. Rehman, L. Jingdong and D. Dean, 2016. Impact of government expenditure on agricultural sector and economic growth in Pakistan. American-Eurasian Journal of Agricultural \& Environmental Sciences, 16(8): 1441-1448.

Alkali, R.A., 1997. The World Bank and Nigeria: Cornucopia or pandora box. Kaduna: Baraka Press.

Andrew, A.O., 2015. Agricultural financing and optimising output for sustainable economic development in Nigeria: An empirical analysis. Journal of Emerging Trends in Economics and Management Sciences, 6(5): 359-366.

Ariyo, A., 1999. Appropriateness of development financing mix of sub-Saharan African economies: Evidence from Nigeria. The Nigerian Journal of Economic and Social Studies, 41(1): 159-173.

Bakare, A. and F. Fawehinmi, 2011. An econometric study of the contribution of oil sector to the standard ofliving in Nigeria 1975-2008. Asian Journal of Business and Management Sciences, 1(3): 1-8.

Bali, S.R., 2001. Demand, segmentation and rationing in the rural credit markets of Puri. Doctoral Dissertation, Acta Universitatis Upsaliensis.

CBN, 2016. Statistical bulletin. Abuja: Central Bank of Nigeria.

Comfort, M.A. and T.O. Arigbede, 2016. The effect of agricultural productivity on economic growth in Nigeria. Journal of Advances in Social Science Humanities, 2(4): 26-33.Available at: https://doi.org/10.15520/jassh2446.

Dang, T.B., 2017. The impact of the credit guarantee system on Hungarian economy. Miskolc: ResearchGate, University of Miskolc, Department of Economics.

Duong, P.B. and Y. Izumida, 2002. Rural development finance in Vietnam: A microeconometric analysis of household surveys. World Development, 30(2): 319-335.Available at: https://doi.org/10.1016/s0305-750x(01)001 12-7.

Edet, B.N., M.E. Edet and D.I. Agom, 2016. Impact of institutional funding on agricultural labour productivity in Nigeria: A cointegration approach. Agricultural Science Research Journal, 6(2): 49-55. 
Egwu, P.N., 2016. Impact of agricultural financing on agricultural output, economic growth and poverty alleviation in Nigeria. Journal of Biology, Agriculture and Healthcare, 6(2): 36-42.

Enrique, B.A., G.O. Camilo, M.D. Blanca and E.A. Dwi, 2012. Agriculture public spending and growth in Indonesia. Policy Research Working Paper No. 5977, The World Bank, Poverty Reduction and Economic Management Unit, East Asia Region.

Evbuomwan, G.O., L.U. Okoye and O.P. Eke, 2018. Effect of government and private sector financing on the agricultural sector in Nigeria. 31st International Business Information Management Association Conference (IBIMA). Milan, Italy: IBIMA. pp: 6795-6812. Available from: http://eprints.covenantuniversity.edu.ng/11086/1/Binder3.pdf.

Friday, O.A., O. Chris and K. Ikechukwu, 2016. Credit supply and agricultural production in Nigeria: A vector autoregressive (VAR) approach. Journal of Economics and Sustainable Development, 7(2): 131-143.

Goffman, I.J., 1968. On the empirical testing of Wagner's law: A technical note. Public Finance, 22(4): 423-461.

Gupta, S.P., 1967. Public expenditure and economic growth a time-series analysis. Public Finance-Finances Publiques, 22(4): 423-454.

Halicioĝlu, F., 2003. Testing Wagner's law for Turkey, 1960-2000. Review of Middle East Economics and Finance, 1(2): 129140.Available at: https://doi.org/10.2202/1475-3693.1007.

Ibe, S.O., 2014. The impact of banks' and public sector's financing activities on agricultural output in Nigeria. Journal of Agriculture and Environmental Sciences, 3(2): 129-143.

Ibok, O.W. and N.E. Bassey, 2014. Wagner's law revisited: The case of Nigerian agricultural sector (1961 - 2012). International Journal of Food and Agricultural Economics, 2(3): 19-32.

Idoko, H., A. Sunday and A. Sheri, 2012. Government expenditure on agriculture and agricultural output in Nigeria (1995 2010). Journal of Agriculture and Veterinary Sciences, 4(9): 7-22.

Ishola, S., S. Olaleye, E. Ajayi and E. Femi, 2013. Government expenditure on agricultural sector and economic growth in Nigeria (1981 - 2010). IOSR Journal of Humanities and Social Science, 8(4): 62-67.Available at: https://doi.org/10.9790/0837-0846267.

Jhingan, M.L., 2004. Money banking, international trade and public finance. India: Vrinda Publications Ltd.

Kareem, R.O., H.A. Bakare, K.A. Raheem, S.E. Ologunla, O.O. Alawode and G.R. Ademoyewa, 2013. Analysis of factors influencing agricultural output in Nigeria: Macroeconomics Perspectives. American Journal of Business, Economics and Management, 1(1): 9-15.

Kuznets, S., 1961. Economic growth and contribution of agriculture: Notes on measurement. International Journal, Agrarian Affairs, 3(2): 56-75.

Landau, D., 1983. Government expenditure and economic growth: A cross-country study. Southern Economic Journal, 49(3): 783-792.Available at: https://doi.org/10.2307/1058716.

Mann, A.J., 1980. Wagner's law: An econometric test for Mexico, 1925-1976. National Tax Journal (Pre-1986), 33(2): $189-201$.

Matthew, A. and B.D. Mordecai, 2016. The impact of public agricultural expenditure on agricultural output in Nigeria (19812014). Asian Journal of Agricultural Extension, Economics \& Sociology, 11(2): 1-10.Available at: https://doi.org/10.9734/ajaees/2016/25491.

Mbat, D.O., 2001. Financial management. Uyo: Dome S. Associates Publishers.

Murthy, N., 1994. Wagner's law, spurious in Mexico or misspecification: A reply. Public Finance= Finances Publiques, 49(2): 295-303.

Musgrave, R.A., 1969. Fiscal systems. New Haven: Yale University Press.

Obansa, S.A. and I.M. Maduekwe, 2013. Agriculture financing and economic growth in Nigeria. European Scientific Journal, 9(1): 168-204.

Odoemenem, I. and C. Obinne, 2010. Assessing the factors influencing the utilization of improved cereal crop production technologies by small-scale farmers in Nigeria. Indian Journal of Science and Technology, 3(1): 180-183. 
Ogen, O., 2003. Patterns of economic growth and development in Nigeria since 1960. Essays in Nigerian contemporary history. Lagos: First Academic Publishers.

Okoh, A.S., 2015. Impact of fiscal policy on the growth of agricultural sector in Nigeria, 1981-2013. European Journal of Educational and Development Psychology, 3(4): 1-17.

Okuneye, P.A., 1995. Nigerian agriculture on the run refuses to move university of agriculture. Abeokuta Inaugural Lecture.

Onwumere, J., I.G. Ibe and I. Ihegboro, 2012. Has the agricultural credit guarantee scheme fund any impact on agricultural productivity in Nigeria? A look at empirical evidence. International Journal of Current Research, 4(3): 190-197.

Oparinde, L.O., T.T. Amos and M. Adeseluka, 2017. Influence of agricultural credit guarantee scheme fund (ACGSF) on fishery development in Nigeria. Scientific Papers Series Management, Economic Engineering in Agriculture and Rural Development, 17(1): 323-332.

Orok, A.B. and S.A. Ayim, 2017. The impact of agricultural credit guarantee scheme fund on agricultural sector development in Nigeria. International Review of Management and Business Research, 6(3): 1104-1116.

Peacock, A.T. and J. Wiseman, 1961. The growth of public expenditure in the United Kingdom. London: Oxford University Press.

Rahji, M. and S. Fakayode, 2009. A multinomial logit analysis of agricultural credit rationing by commercial banks in Nigeria. International Research Journal of Finance and Economics, 24(91): 97-103.

Schreiner, M. and J. Yaron, 2001. Development finance institutions: Measuring their subsidy. Washington D.C: The World Bank.

Swinnen, J.F. and H.R. Gow, 1999. Agricultural credit problems and policies during the transition to a market economy in Central and Eastern Europe. Food Policy, 24(1): 21-47.Available at: https://doi.org/10.1016/s0306-9192(98)00067-0.

Talknice, S. and A. Mufaro, 2014. Agricultural expenditure and economic performance in Zimbabwe (1980-2005). International Journal of Economic Research, 5(5): 50-59.

Udoka, C.O., D.O. Mbat and S.B. Duke, 2016. The effect of commercial banks' credit on agricultural production in Nigeria. Journal of Finance and Accounting, 4(1): 1-10.

Wagner, A., 1893. Three extracts on public finance, in Musgrave R.A. and Peacock A.T. (eds) (1958), Classics in the theory of public finance. London: Macmillan.

Zakaree, S.S., 2014. Impact of agricultural credit guarantee scheme fund (ACGSF) on domestic food supply in Nigeria. British Journal of Economics, Management \& Trade, 4(8): 1273-1284.Available at: https://doi.org/10.9734/bjemt/2014/6441.

Views and opinions expressed in this article are the views and opinions of the author(s), International Journal of Sustainable Agricultural Research shall not be responsible or answerable for any loss, damage or liability etc. caused in relation to/arising out of the use of the content. 